UDC 616-099

DOI: $10.21668 /$ health.risk/2020.2.16.eng

\title{
PROCEDURE FOR PREDICTING PROGRESSING HEPATIC FIBROSIS IN PATIENTS WITH HUMAN IMMUNODEFICIENCY AND HEPATITIS C COINFECTION
}

\author{
V.V. Maslyakov, M.S. Aristanbekova \\ «Reaviz» Medical University, 227 Chapaevskaya Str., Samara, 443001, Russian Federation
}

\begin{abstract}
Our research goal was to develop a system for predicting nature of fibrosis processes in patients infected with HIV and Hepatitis $C$ virus and to assess its efficiency bearing in mind peculiarities of anti-virus therapy applied for treating the infections.

Research was performed on 459 patients with confirmed HIV/viral hepatitis $C$ who had been treated for 1 year at Saratov Regional Center for AIDS Prevention and Elimination. Most patients were males younger than 36. 72-78\% patients had 3-4A $H I V$ infection stages. The rest had $4 B-C$ stages. $32 \%$ were treated only with sets of anti-retroviruses medications made up of nucleoside and non-nucleoside inhibitors of reverse transcriptase, inhibitors of protease, and inhibitors of integrase in different combinations. $14 \%$ patients infected with both HIV and Hepatitis C virus were treated only with antiviral medications aimed for treating hepatitis $C$ and made up of pegylated interferon $\alpha$ and ribavirin or medications with direct effects such as sofosbuvir and daclatasvir. $19 \%$ patients were prescribed both antiviral therapy aimed at treating Hepatitis $C$ and anti-retrovirus therapy.

Research results allowed establishing risk criteria for progressing hepatic fibrosis; they included fibro scanning of liver, number of $C D 3+C D 4+$ cells in blood, and immune regulatory index. Basing on the research data, we created an integral parameter for assessing quantitative risk criteria that could be used when a patient was examined for the first time or during a short-term observation period.

Key words: HIV/Hepatitis C co-infection, infection process, progressing hepatic fibrosis, fibro scanning, T-lymphocytes subpopulations, antiviral therapy, high risk index, risk criteria.
\end{abstract}

HIV/hepatitis $\mathrm{C}$ virus (HCV) coinfection doesn't only tend to have more severe clinical course but also predetermines high lethality among patients due to rapidly developing damage to the liver. It is also known that HIVinfected patients who also have hepatitis $\mathrm{C}$ run higher risks of extrahepatic symptoms [1] and hepatotoxic effects produced by anti-retrovirus (ARV) medications [2]. Given all that, an issue related to progressing liver fibrosis is becoming most outstanding together with problems that doctors have to face when treating chronic hepatitis $\mathrm{C}(\mathrm{CHC})$ in patients coinfected with $\mathrm{HIV} / \mathrm{HCV}$. Over the recent years, a new strategy has been developed regarding $\mathrm{CHC}$ treatment exactly in case there is HIV/HCV coinfection. Up to now, a combination of pegylated recombinant interferon $\alpha(\mathrm{IFN} \alpha)$ and Ribavirin has been considered the only anti-virus therapy against $\mathrm{CHC}$; a procedure for applying it depended on $\mathrm{HCV}$ genotype. This treatment usually involves multiple side effects. A large group of patients who suffered from neuropsychological or cardiovascular disorders could not be treated with interferons due to serious contraindications $[3,4]$. Use of this treatment scheme usually results in persistent anti-virus response only approximately in $40 \%$ when it comes to people who simultaneously have HIV and HCV [5].

In 2011 a new era began as innovative anti-virus medications with direct effects on $\mathrm{HCV}$ were first implemented into treatment practices. Infectiologists started to use NS3/4A inhibitors of HVC proteases (Telaprevir and Boceprevir) to treat HVC infection caused by a virus with genotype 1 combined with pegylated interferon $\alpha$ and Ribavirin [6,7]. As the trend developed, new medications were created with a wider range of effects produced on $\mathrm{HCV}$ and it was possible to use them without IFN [8]. However, a new problem occurred; there was a probability that anti-retrovirus agents and medications with direct effects applied to treat $\mathrm{HCV}$ infection would interact with each other [9].

(C) Maslyakov V.V., Aristanbekova M.S., 2020

Vladimir V. Maslyakov - Doctor of Medical Sciences, Professor, Vice Rector responsible for research (e-mail: maslyakov@inbox.ru; tel.: +7 (903) 023-71-69; ORCID: https://orcid.org/0000-0002-1788-0230).

Maira S. Aristanbekova - Post-graduate student at the Department for Clinical Medicine (e-mail: saratov@reaviz.ru; tel.: +7 (4952) 74-27-21; ORCID: https://orcid.org/0000-0003-2119-5225). 
All the above mentioned problems are extremely urgent for the contemporary infectiology and finding solution to them sets another task that clinical medicine has to solve, namely, the necessity to create a system for precise prediction on how fast liver fibrosis will progress in patients infected with both HIV and HCV. Such a system should be based on existing diagnostic techniques and its goal should be subsequent development of recommendations on relevant treatment procedures. Nowadays it is obvious that HCV progresses much more rapidly in HIVinfected people $[10,11]$ hence HIV-infection considerably (by 2-5 times) increases frequency of acute hepatitis $\mathrm{C}$ transforming into chronic one, makes for development of liver cirrhosis, hepatocellular carcinoma, and liver decompensation up to total loss of all its vital functions [12]. And approximately $60 \%$ lethal outcomes in case of $\mathrm{HIV} / \mathrm{HCV}$ coinfection are exactly due to fatal damage to the liver [13]. To estimate efficiency of anti-virus therapy applied to treat HIV/HVC coinfection is rather complicated; it can also be due to interactions between anti-retrovirus and anti-HCV medications [9, 14-20]. A system was created for detecting high risks of progressive liver fibrosis in patients with HIV/HCV coinfection; it included creating a quantitative integral parameter for risk assessment as well as an algorithm that could be used to calculate it and provide ways to apply it for determining relevant anti-retrovirus and anti-HCV therapy.

Our research goal was to develop a system for predicting fibrosis development in patients with $\mathrm{HIV} / \mathrm{HCV}$ coinfection and to estimate its efficiency bearing in mind peculiarities related to anti-virus therapy applied to treat the infectious process.

Data and methods. Over 1 year we observed 459 patients with verified HIV/HCV coinfection who were treated at Saratov Regional Center for AIDS Prevention and Elimination (AIDS Center). We applied the following criteria to select patients for our research: verified HIVinfection and chronic hepatitis $\mathrm{C}$; absence of etiotropic therapy against $\mathrm{HCV}$ at the moment the research was accomplished; 3-4B HIV infections stages acceding to V.I. Pokrovskiy's classification; more or less apparent drug addiction in patients; age from 25 to 57; given informed consent to take part in the research.
We also applied several criteria for excluding a patient from the research; they were severe concomitant somatic and mental diseases, obesity; concomitant autoimmune and allergic diseases, a patient being often sick for a long period of time; viral hepatitis of other etiology (not $\mathrm{CHC}$ ), autoimmune hepatitis, damage to the liver caused by medications, liver steatosis; a refusal to take part in the research. Most examined patients were males younger than 36 . $72-78 \%$ had $3-4 \mathrm{~A}$ HIV infection stages; the rest had 4B-4C. Approximately $67 \%$ patients had HCV $1 \mathrm{~b}$ genotype; $1 \%$, 2a genotype; the rest, 3a genotype. All the patients underwent transient liver elastography throughout the research; the results were given in $\mathrm{kPa}$. A stage in fibrosis was estimated according to METAVIR scale. As per initial data, $40 \%$ patients didn't have any fibrosis changes in their liver (F0 stage); $20 \%$ had the first stage when fibrosis just occurred (stage F1); $16 \%$ had significant fibrosis (stage F2); $8 \%$ has apparent fibrosis (stage F3); and $16 \%$ already had cirrhosis (stage F4). $35 \%$ patients were not treated with anti-virus medications. $32 \%$ had only antiretrovirus therapy that involved applying medications from groups of nucleoside and nonnucleoside reverse transcriptase inhibitors, inhibitors of protease and integrase in different combinations. $14 \%$ patients with $\mathrm{HIV} / \mathrm{HCV}$ coinfection were treated only with anti-HCV therapy based on pegylated interferon $\alpha$ and Ribavirin or direct effect medications, such as Sofosbuvir and Daclatasvir. $19 \%$ patients received both anti-HCV therapy and antiretrovirus therapy. All the patients had their $\mathrm{HIV} / \mathrm{HCV}$ coinfection verified via laboratory research (serologic examinations with ELISA test, immune blotting, and PCR diagnostics); besides, throughout the research, they underwent laboratory monitoring that involved clinical and biochemical blood tests, determination of HIV and HCV viral load in blood with PCR in real time mode, and immunologic examinations with flow cytofluorometry.

ELISA test was performed to determine antibodies - HIV and viral hepatitis C infection markers in blood serum; it was done with «Dynex MRX II» microplate reader (Dynextechnologies, the USA) basing on "Abbot» diagnostic test-systems (the USA). The exami- 
nation was accomplished in conformity with the user guide provided for the device and test systems. Immune blotting was performed to determine HIV-1 proteins in blood serum; it was done with electrophoresis equipment together with «GelDoc» software package (Bio-Rad, the USA) and «Genescreen Plus HIV Ag-AB» test system (Bio-Rad, USA) in conformity with the user guide provided for the device and test systems. Polymerase chain reaction (PCR) was applied to determine HIV and HCV RNA in blood, viral load with HIV and HCV, and HCV genotype; it was done with «COBAS 50 TaqMan 48» PCR analyzer with an automated device for sample preparation «COBAS ${ }^{\circledR}$ AmpliPrep» (Roche Diagnostic Systems, the USA). The research included the following stages: RNA extraction (sample preparation), reverse transcription reaction, PCVR-amplification to HIV DNA in real time mode in order to quantitatively determine viral load in conformity with the user guide provided for the device and reagents. Qualitative and quantitative determination of HCV RNA in blood plasma was performed with Hoffman-La-Roche test-system with its sensitivity being equal to $15 \mathrm{ME} / \mathrm{ml}$. Transient liver fiber elastography was made with «Fibroscan» (France). All the patients underwent the procedure prior to treatment and 48 weeks after (when treatment was over) with determining fibrosis stage according to METAVIR scale and results given in $\mathrm{kPa}$. We also performed clinical examination of peripheral blood that involved calculating blood corpuscles per 1 unit of volume; it was done with «SWELAB AlfaBasic» automated hematologic analyzer (Sweden). We applied thrombocytes* number equal to $109 / 1$ in our research. Biochemical blood analysis was performed with «FURUNO 270» automated biochemical analyzer (Japan); it involved determining aspartate aminotransferase (AST), $\mu \mathrm{mol} / \mathrm{min} .1$; alanine51-aminotrasferase (ALT), $\mu \mathrm{mol} / \mathrm{min} .1$; alkaline phosphatase (AP), $\mu \mathrm{mol} / \mathrm{min} .1$; lactate dehydrogenase (LDG), $\mu \mathrm{mol} / \mathrm{min} .1$; total protein, $\mathrm{g} / \mathrm{l}$; albumin, $\mathrm{g} / \mathrm{l}$; overall and conjugated bilirubin, $\mu \mathrm{mol} / \mathrm{l}$; cholesterol, g/l; dextrose, g/l. Flow cytofluorometry was performed to determine immunologic parameters with «FACS Calibur» device (Beckton Dickinson, the USA) after blood sample were automatically prepared with BD FACS SamplePrepAssistant II device (Becton Dickin- son, the USA) in conformity with the user guide provided for the devices and monoclonal antibodies. We processed all the obtained data with FACS Diva software. Determination was accomplished basing on BD Multitest 6- Color TBNK Reagent, a standardized monoclonal antibodies set (BD Biosciences, the USA). We analyzed absolute number of CD3+CD4+ lymphocytes (T-helpers and CD3+CD8+ cells (cytotoxic T-lymphocytes) in blood. Immune regulatory index (IRI) was calculated as per the following formula basing on the research results: $\mathrm{IRI}=\mathrm{CD} 3+\mathrm{CD} 4+/ \mathrm{CD} 3+\mathrm{CD} 8+$.

All the data were statistically processed with SPSS software (Version 21) in conformity with the user guide provided for it.

Results and discussion. To assess liver fibrosis development in patients with HIV and HCV coinfection, we distributed all the patients into several groups according to fibrosis process each of them had (progressive, stable, or regressive). The examination was based on data obtained via transient elastography performed for each patient, both at the moment the observation started and when it ended 1 year after. The disease was considered to be progressing in case liver elastography parameters increased by more than $10 \% 1$ year after and fibrosis moving on to the next stage; the disease was regressive if elastography parameters decreased by more than $10 \%$, and a patient returned to the previous stage in fibrosis process. Fibrosis was considered to be stable in all other cases. As a result, it turned out that $16 \%$ out of 459 observed patients coinfected with $\mathrm{HIV} / \mathrm{HCV}$ had progressive fibrosis; $65 \%$, stable; and $19 \%$, regressive (Table).

Relevance of this approach to fibrosis process estimation found its statistical confirmation. Thus, in case the disease was progressive, there was a statistically authentic transition from initial median in elastography parameters equal to $6.7 \mathrm{kPa}$ to $7.7 \mathrm{kPa} 1$ year after (approximately $15 \%$ growth). There were practically no changes in median when the disease was stable as it was equal to $5.8 \mathrm{kPa}$ in both tests. In case the disease was regressive, median went down authentically, from $7.7 \mathrm{kPa}$ to $5.8 \mathrm{kPa}$, that is, approximately by $13 \%$. We were the first to apply such an approach to data consolidation and there are no analogues to our research in available scientific literature. 
Table

Dynamics of elastography parameters in compliance with fibrosis course in patients coinfected with $\mathrm{HIV} / \mathrm{HCV}$

\begin{tabular}{|l|c|c|c|}
\hline \multirow{2}{*}{\begin{tabular}{c}
\multirow{2}{*}{$\begin{array}{c}\text { Liver } \\
\text { fibrosis course }\end{array}$} \\
\cline { 2 - 3 }
\end{tabular}} & \multicolumn{2}{|c|}{$\begin{array}{c}\text { Elastography parameters } \\
(\mathrm{kPa}) \text { : median [min; max }]\end{array}$} & \multirow{2}{*}{$p$} \\
\cline { 2 - 3 } & initial & 1 year after & \\
\hline Progressive $(n=73)$ & $6.7[4.0 ; 12.9]$ & $7.7[4.0 ; 28.0]$ & $<0.001$ \\
\hline Stable $(n=297)$ & $5.8[2.8 ; 75.0]$ & $5.8[3.0 ; 75.0]$ & 0.950 \\
\hline Regressive $(n=89)$ & $7.7[4.7 ; 22.5]$ & $5.8[3.5 ; 15.4]$ & $<0.001$ \\
\hline
\end{tabular}

Note:

$n$ is a number of patients in a group;

$p$ is probability of discrepancy between initial data and data obtained 1 year after;

Validity of discrepancy as per Mann-Whitney test at $p<0,05$ is colored grey.

The next stage in the research focused on determining instrumental and laboratory-immunologic criteria that could be used to identify patients coinfected with $\mathrm{HIV} / \mathrm{HCV}$ who ran high risks of adverse fibrosis course. Our quantitative parameters were those obtained via elastography as well as routine hematologic, biochemical, virologic, and immunologic data that are conventionally applied to monitor liver fibrosis in patients with $\mathrm{CHC}$ or HIV infection including those coinfected with both viruses. These parameters included disorders in liver tissue elasticity given in $\mathrm{kPa}$; number of thrombocytes; ALT; AST; alkaline phosphatase; LDH; total protein and albumin; total bilirubin; cholesterol; dextrose; viral load with HIV; viral load with $\mathrm{HCV}$; number of CD3+CD4+ and CD3+CD8+ lymphocytes; immune regulatory index. Our statistical analysis revealed that elastography parameters allowed determining groups with high and low risks quite precisely. In particular, values higher than $7 \mathrm{kPa}$ were typical for patients with high risks. There weren't any routine hematologic or biochemical data that would show statistically authentic differences between coinfected patients with different fibrosis course. As for immunologic blood parameters, we should note that they all authentically deviated from the control but their differences depending on a risk of progressive fibrosis were limited to only two parameters, namely number of T-helpers $(\mathrm{CD} 3+\mathrm{CD} 4+)$ and immune regulatory index. We statistically estimated whether deviations in these parameters had any predictive value and revealed that in case a number of T-helpers is lower than 400 cells $/ \mathrm{ml}$, it allows predicting that a patient belongs to a group with high risks; predictive value is quite high (AUROC $=0.818$ ). The same goes for IRI being lower than 0.45 (AUROC $=0.793$ ).

Therefore, several parameters can be considered risk criteria that indicate there are high risks of progressive fibrosis. They are liver elastography parameters, number of $\mathrm{CD} 3+\mathrm{CD} 4+$ cells in blood, and immune regulatory index. Basing on these data, we developed an integral parameter for assessing quantitative risk criteria that could be used in case a patient applied for medical aid for the first time or was observed by a doctor over a short period of time. To do that, we performed regression analysis of all obtained quantitative data in determined groups with high and low risks of progressive fibrosis. When performing this analysis, we took the following data as our independent variables: initial liver elastography parameters, number of T-helpers, and immune regulatory index; our dependent variable was a score estimate of risk factors; and a variable showing selection of observations was a patient belonging to a group with high risks of progressive fibrosis. We got the following regression equation: $\mathrm{HRI}=4.070+0.099 \cdot \mathrm{kPa}+$ $+0.476 \cdot \mathrm{CD} 4-0.518 \cdot \mathrm{IRI}$, where $\mathrm{kPa}$ is initial elastography parameter, CD4+ is an absolute number of $\mathrm{CD} 3+\mathrm{CD} 4+$ cells $/ \mathrm{ml}$ of blood, and IRI is immune regulatory index. Finding solution to this equation gave us «high risk index» (HRI) for progressive liver fibrosis. We determined $95 \%$ confidence interval of HRI in groups of patients coinfected with $\mathrm{HIV} / \mathrm{HCV}$ with high and low risks and revealed its high predictive value $(A U R O C=0.846)$ in case it was lower than 180 . This stage in our research is top priority.

Two last stages in the research involved testing the high risk index for adverse fibrosis course in patients coinfected with $\mathrm{HIV} / \mathrm{HCV}$ in order to prescribe or adjust anti-retrovirus therapy, anti-virus therapy for treating $\mathrm{CHC}$, or to correctly combine anti-retrovirus therapy and anti-virus therapy for treating $\mathrm{CHC}$.

Let us give several clinical cases from a pool of our own observations.

Clinical case No.1. The following data were taken from a case history of a patient with $\mathrm{HIV} / \mathrm{HCV}$ who was treated with anti-retrovirus therapy. They illustrate that liver fibrosis progressed rapidly against a combination of 


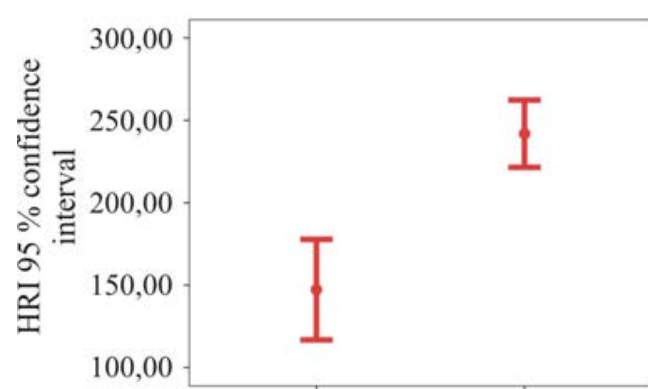

High risk group Low risk group

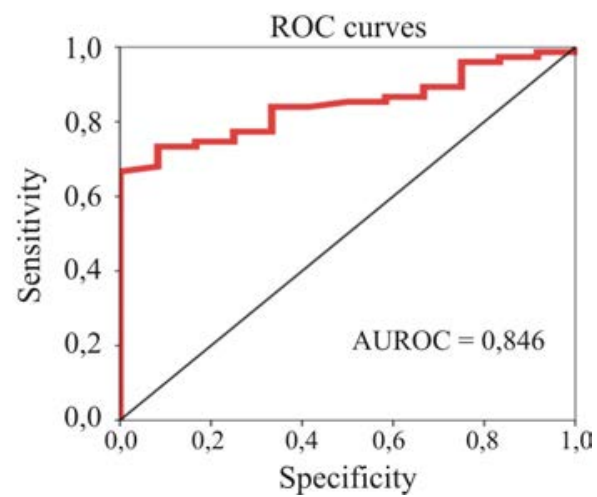

Figure. 95\% -confidence intervals and ROC-curves of $\mathrm{HRI}$ in groups of patients coinfected with $\mathrm{HIV} / \mathrm{HCV}$ with high and low risks of progressive liver fibrosis

nucleoside reverse transcriptase inhibitors and non-nucleoside reverse transcriptase inhibitors. Patient Z. was 36 years old and was treated at an outpatient department at "AIDS Center». The diagnoses were «HIV-infection, stage 4A» and «Chronic hepatitis $\mathrm{C}$, virus reproduction stage». The patient got infected with both viruses due to intravenous injections of psychoactive drugs (PAD). At the moment the patient was included into our research, it was established that he had got infected with hepatitis $\mathrm{C}$ in 2002 and with HIV even earlier, in 2000. At present the patient states that he doesn't take any PAD and drinks only beer, 1.0-1.5 liters per week. He has not been given any antivirus therapy before. His height and weight were last measured on August 01, 2015, $169 \mathrm{~cm}$ and $57 \mathrm{~kg}$ accordingly. He feels rather satisfactory but still complaints about weakness and rapid fatigue. Objective data obtained via a medical examination are as follows: skin and visible mucosas have normal color and are clean. Peripheral lymph nodes (cervical, submaxillary, and axillary) are enlarged. Vesicular breath can be heard in the lungs and there are no rales there. Heart sounds are muffled, heart rhyme is normal, there are no noises, and heart rate is
78 strokes per minute. Blood pressure is $125 / 75$ $\mathrm{mm} \mathrm{Hg}$. Body temperature is $36.7^{0} \mathrm{C}$. Stomach is soft with no pains in any section during palpation; the liver goes beyond the coastal margin by $1 \mathrm{~cm}$, its edge is smooth and even and its surface is elastic. The spleen is enlarged. The patient feels no pains when being punched slightly at both sides. Defecation and urination are normal. Consciousness is clear. There are no focal or meningeal symptoms. Blood test results are as follows: hemoglobin is $146 \mathrm{~g} / \mathrm{l}$; thrombocytes, $175.0 \cdot 10^{9} / 1$; leukocytes, $7.3 \cdot 10^{9} / 1$. Urine test hasn't revealed any pathology. Biochemical blood test results are as follows: ALT is $53 \mathrm{IU} / 1$; AST, $51 \mathrm{IU} / 1$; total bilirubin, $13.6 \mathrm{mmol} / \mathrm{l}$; LDH, $231 \mathrm{IU} / 1$. Immunity parameters are as follows: CD4+ lymphocytes, 95 cells $/ \mathrm{ml}$; CD8, 741 cells $/ \mathrm{ml}$; IRI is 0.26 . PCR test revealed HCV RNA in quantity equal to $1.7 \cdot 10^{6} \mathrm{IU} / \mathrm{ml}$, virus genotype $1 \mathrm{~b}$, and HIV RNA in quantity equal to 121,300 copies $/ \mathrm{ml}$. Ultrasound scanning of the abdominal cavity has revealed hepatomegaly, diffuse changes in liver parenchyma, and splenomegaly. Performed liver elastography showed first stage fibrosis (F1) with the parameter being $6.1 \mathrm{kPa}$ as per METAVIR scale. A board of doctors, having taken into account immunologic parameters, viral load, and liver elastography results, prescribed the patient anti-retrovirus therapy (ARVT) as a combination of nucleoside reverse transcriptase inhibitors (Zidovudine + Lamivudine) and non-nucleoside reverse transcriptase inhibitors (Efavirenz). ARVT was applied for 6 months and it resulted in a decrease in viral load with HIV RNA down to indefinable level (less than 20 copies $/ \mathrm{ml}$ ); also, immunologic parameters improved as CD4+ grew to 240 cells $/ \mathrm{ml}$, and $\mathrm{CD} 8+$, to 857 cells $/ \mathrm{ml}$, IRI rose to 0.28 . But biochemical blood test showed deterioration in ALT, $199 \mathrm{IU} / \mathrm{ml}$; AST, $201 \mathrm{IU} / \mathrm{ml}$, total bilirubin rose to $26 \mathrm{mmol} / \mathrm{L}$, and direct bilirubin, to $5.8 \mathrm{mmol} / \mathrm{L}$. Overall blood test showed a decrease in thrombocytes concentration down to $110 \cdot 10 \mathrm{~g} / \mathrm{L}$; hemoglobin, $115 \mathrm{~g} / \mathrm{L}$. Liver elastography revealed that fibrosis had progressed to stage $\mathrm{F} 3$ and the parameter was equal to 11.8 as per METAVIR scale. We applied a formula for calculating an index showing adverse fibrosis course in patients coinfected with HIV and HCV in order to prescribe 
new therapy or correct the existing one; the value was less than 180 and it indicated that the patient belonged to a group with high risks of progressive fibrosis.

$$
\begin{gathered}
\mathrm{HRI}=4.070+0.099 \cdot 11.8 \mathrm{kPa}+ \\
+0.476 \cdot 240 \text { cells } / \mathrm{ml}-0.518 \cdot 0.28=119.33
\end{gathered}
$$

Given that, a board of doctors took a decision to change ARVT scheme and apply a combination of nucleoside reverse transcriptase inhibitors (Zidovudine+Lamivudine) and protease inhibitors (Kaletra). The patient was being observed during the next 6 months after the scheme had been changed to the above said medications; 6 months after there was regress in fibrosis process to stage F2 with the parameter going down to $7.4 \mathrm{kPa}$; another 6 months after fibrosis regressed to stage $\mathrm{F} 1$ and the parameter was $6.3 \mathrm{kPa}$. Immunologic parameters improved as there was $38 \%$ growth in $\mathrm{CD} 4+$ quantity up to 240 cells/ml. HIV RNA concentration was still indefinable (less than 20 copies/ml) and viral load with HCV RNA remained the same at $1.5 \cdot 10^{6} \mathrm{IU} / \mathrm{ml}$. In this case it is impossible to prescribe any anti-viral therapy against hepatitis $\mathrm{C}$ due to low immunological parameters, namely quantity of $\mathrm{CD} 4+$ cells in blood being less than 500 cells $/ \mathrm{ml}$. But we can apply HRI formula to select an optimal antiviral therapy scheme that in future will allow reaching such parameters that will make antiviral therapy against $\mathrm{CHC}$ possible and, consequently, will secure regress in fibrosis process.

Clinical case No.2. The following data were taken from a case history of a patient with $\mathrm{HIV} / \mathrm{HCV}$ who was treated with anti-retrovirus therapy. They illustrate that liver fibrosis regressed due to a combination of nucleoside reverse transcriptase inhibitors and protease inhibitors. Patient T. was 45 years old and was treated in an outpatient department at «AIDS Center». The diagnoses were «HIV-infection, stage 4A» and "Chronic hepatitis $\mathrm{C}$, virus reproduction stage». The patient got infected with both viruses due to intravenous injections of psychoactive drugs (PAD). At the moment the patient was included into our research, it was established that he had got infected with hepatitis C in 2001 and with HIV even earlier, in 2000. At present the patient states that over the last 5 years he hasn't been taking any PAD and hasn't been drinking alcohol. Previously in
2006 he was prescribed anti-retrovirus therapy but he ceased taking the prescribed medications one month after and was excluded from the treatment program. His height and weight were last measured on December 17, 2014, $178 \mathrm{~cm}$ and $67 \mathrm{~kg}$ accordingly. He feels rather satisfactory but still complaints about weakness and heaviness in the right hypochondrium that sometimes appears under physical loads and/or when he doesn't stick to a healthy diet. Objective data obtained via a medical examination are as follows: skin and visible mucosas have normal color and are clean. Peripheral lymph nodes (cervical, submaxillary, and axillary) are not enlarged. Vesicular breath can be heard in the lungs and there are no rales there. Heart sounds are muffled, heart rhyme is normal, there are no noises, and heart rate is 78 strokes per minute. Blood pressure is $120 / 80 \mathrm{~mm} \mathrm{Hg}$. Body temperature is $36.7^{0} \mathrm{C}$. Stomach is soft with no pains in any section during palpation; the liver goes beyond the coastal margin by $2 \mathrm{~cm}$, its edge is smooth and even and its surface is elastic. The spleen is enlarged. The patient feels no pains when being punched slightly at both sides. Defecation and urination are normal. Consciousness is clear. There are no focal or meningeal symptoms. Blood test results are as follows: hemoglobin is $137 \mathrm{~g} / \mathrm{l}$; thrombocytes, $109.0 \cdot 10^{9} / 1$; leukocytes, $6.3 \cdot 10^{9} / 1$. Urine test hasn't revealed any pathology. Biochemical blood test results are as follows: ALT is $186 \mathrm{IU} / \mathrm{l}$; AST, $98 \mathrm{IU} / \mathrm{l}$; total bilirubin, $15.2 \mathrm{mmol} / \mathrm{l}$; LDH, $211 \mathrm{IU} / \mathrm{l}$. Immunity parameters are as follows: CD4+ lymphocytes, 555 cells $/ \mathrm{ml}$; CD8, 1,664 cells $/ \mathrm{ml}$; IRI is 0.33 . PCR test revealed HCV RNA in quantity equal to $8.8 \cdot 10^{5} \mathrm{IU} / \mathrm{ml}$, virus genotype $3 \mathrm{a}$, and HIV RNA in quantity equal to 108,231 copies $/ \mathrm{ml}$. Ultrasound scanning of the abdominal cavity has revealed hepatomegaly, diffuse changes in liver parenchyma, and splenomegaly. Performed liver elastography showed the third stage fibrosis (F3) with the parameter being $9.6 \mathrm{kPa}$ as per METAVIR scale.

A board of doctors, having taken into account immunologic parameters, viral load, and liver elastography results, prescribed the patient anti-retrovirus therapy (ARVT) as a combination of nucleoside reverse transcriptase inhibitors (Abacavir + Lamivudine $=$ Kivexa $)$ and protease inhibitors (Prezista). ARVT was 
applied for 6 months and it resulted in a decrease in viral load with HIV RNA down to indefinable level (less than 20 copies/ml); also, immunologic parameters improved as $\mathrm{CD} 4+$ grew to 680 cells $/ \mathrm{ml}$, and CD8+, to 1,458 cells $/ \mathrm{ml}$, IRI rose to 0.46. Biochemical blood test showed the following; ALT, $68 \mathrm{IU} / \mathrm{ml}$; AST, $52 \mathrm{IU} / \mathrm{ml}$, total bilirubin fell to $10.3 \mathrm{mmol} / \mathrm{L}$, and direct bilirubin, to $5.2 \mathrm{mmol} / \mathrm{L}$. Overall blood test showed an increase in thrombocytes concentration up to $137 \cdot 10 \mathrm{~g} / \mathrm{L}$; hemoglobin, $135 \mathrm{~g} / \mathrm{L}$. Liver elastography revealed that fibrosis had regressed from stage $\mathrm{F} 3(9.6 \mathrm{kPa}$ as per METAVIR scale) to F1 with the parameter falling to $7.2 \mathrm{kPa}$. We applied a formula for calculating an index showing adverse fibrosis course in patients coinfected with HIV and $\mathrm{HCV}$ in order to prescribe new therapy or correct the existing one; the value was 323.24 (higher than 180) and it indicated that the patient belonged to a group with low risks of progressive fibrosis.

$$
\begin{gathered}
\mathrm{HRI}=4.070+0.099 \cdot 7.2 \mathrm{kPa}+ \\
+0.476 \cdot 680 \text { cells } / \mathrm{ml}-0.518 \cdot 0.46=323.24
\end{gathered}
$$

Patient didn't need any corrections in ARVT scheme; he continued taking nucleoside reverse transcriptase inhibitors (Abacavir + Lamivudine) combined with a protease inhibitor (Prezista). The patient was being observed during the next 6 months; there was regress in fibrosis process to stage F0 with the parameter going down to $5.3 \mathrm{kPa}$. Immunologic parameters improved with CD4+ quantity up to 720 cells/ml. HIV RNA concentration was still indefinable (less than 20 copies $/ \mathrm{ml}$ ) and viral load with HCV RNA was equal to $8.5 \cdot 10^{5} \mathrm{IU} / \mathrm{ml}$. In December 2015 the patient was prescribed anti-virus therapy against hepatitis $\mathrm{C}$ and treated with pegylated interferon and Ribavirin for 48 weeks; as a result, a persistent virologic response occurred. 24 weeks after anti0vrus therapy was over, HCV RNA was not detected and liver elastography parameter was $\mathrm{F} 0=5.1 \mathrm{kPa}$; biochemical blood parameters were as follows: ALT was $40 \mathrm{UI} / \mathrm{ml}$; AST, $38 \mathrm{UI} / \mathrm{ml}$; total bilirubin, $8.9 \mathrm{mmol} / \mathrm{l}$; direct bilirubin, $1.5 \mathrm{mmol} / \mathrm{l}$; but immunologic blood parameters went down a bit due to interferon therapy, quantity of CD4+ being equal to 514 cells $/ \mathrm{ml}$.

Therefore, doctors managed to achieve complete regress in fibrosis process due to ARVT that combined nucleoside reverse tran- scriptase inhibitors (Abacavir + Lamivudine) with a protease inhibitor (Prezista) with subsequent addition of double antivirus therapy against hepatitis $\mathrm{C}$ (interferon + Ribavirin).

Clinical case No. 3. The following data were taken from a case history of a patient with $\mathrm{HIV} / \mathrm{HCV}$ who was not given any anti-retrovirus therapy. They illustrate liver fibrosis progress against absence of any therapy. Patient A. was 34 years old and was treated at an outpatient department at «AIDS Center». The diagnoses were «HIV-infection, $3^{\text {rd }}$ sub-clinic stage» and «Chronic hepatitis $\mathrm{C}$, minimal activity». The patient got infected with both viruses due to intravenous injections of psychoactive drugs (PAD). At the moment the patient was included into our research, it was established that he had got infected with hepatitis C in 2002 and with HIV much later, in 2015. At present the patient states that he doesn't take any PAD and doesn't drink alcohol. Previously he has not been prescribed antivirus therapy against $\mathrm{HCH}$ or HIV infection. His height and weight were measured on April 02, 2015 when he was first included into a treatment program, $171 \mathrm{~cm}$ and $59 \mathrm{~kg}$ accordingly. He feels rather satisfactory but still complaints about weakness and heaviness in the right hypochondrium that sometimes appears under physical loads and/or when he doesn't stick to a healthy diet. Objective data obtained via a medical examination are as follows: skin and visible mucosas have normal color and are clean. Peripheral lymph nodes (cervical, submaxillary, and axillary) are not enlarged. Vesicular breath can be heard in the lungs and there are no rales there. Heart sounds are muffled, heart rhyme is normal, there are no noises, and heart rate is 78 strokes per minute. Blood pressure is $120 / 85 \mathrm{~mm} \mathrm{Hg}$. Body temperature is $36.7^{\circ} \mathrm{C}$. Stomach is soft with no pains in any section during palpation; the liver goes beyond the coastal margin by $2 \mathrm{~cm}$, its edge is smooth and even and its surface is elastic. The spleen is not palpated. The patient feels no pains when being punched slightly at both sides. Defecation and urination are normal. Consciousness is clear. There are no focal or meningeal symptoms. Blood test results are as follows: hemoglobin is $131 \mathrm{~g} / 1$; thrombocytes, $208.0 .0 \cdot 10^{9} / 1$; leukocytes, $6.8 \cdot 10^{9} / 1$. Urine test hasn't revealed any pathology. Biochemical blood test results are as follows: ALT is $87 \mathrm{IU} / 1$; AST, $78 \mathrm{IU} / \mathrm{l}$; total bilirubin, $5.8 \mathrm{mmol} / \mathrm{l}$; LDH, 
242 IU/l. Immunity parameters are as follows: CD4+ lymphocytes, 635 cells/ml; CD8, 1,432 cells $/ \mathrm{ml}$; IRI is 0.44 . PCR test revealed HCV RNA in quantity equal to $8.7 \cdot 10^{3} \mathrm{IU} / \mathrm{ml}$, virus genotype $3 \mathrm{a}$, and HIV RNA in quantity equal to 9,007 copies/ml. Ultrasound scanning of the abdominal cavity has revealed hepatomegaly, diffuse changes in liver parenchyma, and splenomegaly. Performed liver elastography showed the first stage fibrosis (F1) with the parameter being $6.3 \mathrm{kPa}$ as per METAVIR scale.

A board of doctors, having taken into account immunologic parameters, viral load, and liver elastography results, decided the patient didn't need any anti-retrovirus therapy (ARVT). According to the standards for medical aid provision the patient was to be periodically examined at «AIDS Center». A year after the observation started, viral load with HIV RNA increased to 15,167 copies/ $\mathrm{ml}$, and immunologic parameters deteriorated as $\mathrm{CD} 4+$ went down to $355 \mathrm{cells} / \mathrm{ml}$, and $\mathrm{CD} 8+$, to 806 cells/ml, IRI was 0.44 . Biochemical blood test showed the following; ALT, $137 \mathrm{IU} / \mathrm{ml}$; AST, $80 \mathrm{IU} / \mathrm{ml}$, total bilirubin was up to $20.3 \mathrm{mmol} / \mathrm{L}$, and direct bilirubin, to $6.23 \mathrm{mmol} / \mathrm{L}$. Overall blood test showed a decrease in thrombocytes concentration down to $197 \cdot 10^{9} \mathrm{~g} / \mathrm{L}$; hemoglobin, $125 \mathrm{~g} / \mathrm{L}$. Liver elastography revealed that fibrosis had progressed from stage $\mathrm{F} 1$ (6.3 $\mathrm{kPa}$ as per METAVIR scale) to $\mathrm{F} 3$ with the parameter rising to $9.4 \mathrm{kPa}$. We applied a formula for calculating an index showing adverse fibrosis course in patients coinfected with HIV and HCV in order to prescribe new therapy or correct the existing one; the value was 173.75 (lower than 180) and it indicated that the patient belonged to a group with high risks of progressive fibrosis.

$$
\begin{gathered}
\mathrm{HRI}=4.070+0.099 \cdot 9.4 \mathrm{kPa}+ \\
+0.476 \cdot 355 \text { cells } / \mathrm{ml}-0.518 \cdot 0.44=173.75
\end{gathered}
$$

The patient was immediately offered to take anti-retrovirus therapy but he refused it. In 2017 a scheduled medical check-up revealed liver fibrosis progress from $9.4 \mathrm{kPa}$ to
$10.3 \mathrm{kPa}(\mathrm{F} 3)$. But still, the patient didn't give his informed consent to $\mathrm{HIV} / \mathrm{HCV}$ treatment and was not committed to take any therapy.

Therefore, it is advisable to apply ARVT in case of $\mathrm{HIV} / \mathrm{HCV}$ coinfection not only in order to treat HIB-infections but also to influence fibrosis that occurs under $\mathrm{HCH}$ as it allows inhibiting its active progress.

\section{Conclusions.}

1. There are several quantitative risk criteria for determining risks of progressive liver fibrosis; they were determined basing on work models for high and low risks. They are initial elastography parameters being higher than $7 \mathrm{kPa}$; number of CD3+CD4+ T-lymphocytes in blood being lower than 400 cells $/ \mathrm{ml}$; immune regulatory index being lower than 0.45 ; predictive value of these criteria is either moderate or high (AUROC varying from 0.79 to 0.83 ).

2. The greatest predictive value in determining probable adverse fibrosis course $(A U R O C=0.846)$ belonged to high risk index (HRI) that was determined as per the following linear regression equation: $\mathrm{HRI}=$ $=4.070-0.099 \cdot \mathrm{kPa}+0.476 \cdot \mathrm{CD} 4-0.518 \cdot \mathrm{IRI}$, where $\mathrm{kPa}$ is initial elastography parameter, CD4-is an absolute number of CD3+CD4+ cells $/ \mathrm{ml}$ in blood, IRI is immune regulatory index $\mathrm{CD} 3+\mathrm{CD} 4+/ \mathrm{CD} 3+\mathrm{CD} 8+$.

3 . HRI value being $\leq 180$ indicates that a patient coinfected with $\mathrm{HIV} / \mathrm{HCV}$ runs high risks of adverse fibrosis course and its predictive value is high; determination of this value is a key component in the algorithm applied for diagnostics and treatment of patients coinfected with $\mathrm{HIV} / \mathrm{HCV}$.

4. HRI value being $\leq 180$ in patients coinfected with $\mathrm{HIV} / \mathrm{HCV}$ indicates that antiretrovirus therapy is required and it should combine HIV reserve transcriptase inhibitors and HIV protease or integrase inhibitors.

Funding. The research was not granted any sponsor support.

Conflict of interests. The authors declare there is no any conflict of interests.

\section{References}

1. Scott J.A., Chew K.W. Treatment optimization for HIV/HCV co-infected patients. Ther. Adv. Infect. Dis., 2017, vol. 4, no. 1, pp. 18-36. DOI: 10.1177/2049936116681279

2. Nunez M., Soriano V. Hepatotoxicity of antiretrovirals: incidence, mechanisms and management. Drug. Safety, 2005, vol. 28, no. 1, pp. 53-66. DOI: 10.2165/00002018-200528010-00004

3. Shostakovich-Korets'ka L.R., Shevchenko-Makarenko O.P., Chukhalova I.V., Nosenko O.V. Monitoring of therapy in patients with $\mathrm{HIV} / \mathrm{HCV}$ co-infection who receive antiviral therapy against hepatitis $\mathrm{C}$ and antiretroviral therapy. Aktual'naya infektologiya, 2017, vol. 5, no. 7, pp. 290-292 (in Russian). 
4. Soriano V., Labarga P., Fernandez-Montero J.V. Drug interactions in HIV-infected patients treated for hepatitis C. Expert Opin. Drug. Metab. Toxicol., 2017, vol. 13, no. 8, pp. 807-816. DOI: 10.1080/17425255.2017.1351942

5. Rockstroh J.K. Management of hepatitis C/HIV co-infection. Curr. Opin. Infect. Dis., 2006, vol. 19, no. 1, pp. 8-13. DOI: 10.1097/01.qco.0000200294.22661.e0

6. Aubinskaya G.M., Koval' T.I., Sizova L.M., Rudenko S.S., Limarenko N.P. Optimizatsiya prognozirovaniya tempa progressirovaniya fibroza pecheni u VICh-infitsirovannykh patsientov s khronicheskim gepatitom $\mathrm{C}$ [Optimizing prediction of hepatic fibrosis progress rate in patients infected with HIV and suffering from chronic Hepatitis C. Aktual'naya infektologiya, 2018, vol. 6, no. 5, pp. 258-259 (in Russian).

7. Sobyanina S.N., Yurganova G.A. Substantiation and evaluation of using of peg-modified interferons combined with darunavir for treating of chronic HCV and HIV-infections. VICh-infektsiya i immunosupressii, 2010, vol. 2, no. 3, pp. 118-122 (in Russian).

8. Chen T.Y., Ding E.L., Seage Iii G.R., Kim A.Y. Meta-analysis: increased mortality associated with hepatitis C in HIV-infected persons is unrelated to HIV disease progression. Clin. Infect. Dis., 2009, vol. 49, no. 10 , pp. $1605-1615$. DOI: $10.1086 / 644771$

9. Znoiko O.O. Hard-to-treat patient with hepatitis $\mathrm{C}$ - what will change with interferon-free therapy? Infektsionnye bolezni: novosti, mneniya, obuchenie, 2014, no. 2, pp. 60-67 (in Russian).

10. Del Bello D., Ita Nagy F., Hand J. Direct-acting antiviral-based therapy for chronic hepatitis C virus in HIV-infected patients. J. Curr. Opin. HIV AIDS, 2015, vol. 10, no. 5, pp. 337-347. DOI: 10.1097/COH.0000000000000182

11. Pavlov D.V., Shatrova D.Kh., Galiullin N.I., Nagimova F.I. Peculiarities of HIV-positive patients coinfection with hepatitis C virus. Kazanskii meditsinskii zhurnal, 2014, vol. 95, no. 6, pp. 905-908 (in Russian).

12. Kravchenko A.V., Kanestri V.G., Kuimova U.A. Modern recommendations for using hepatitis C virus protease inhibitors in patients with combined infection (HIV infection/chronic hepatitis C). Infektsionnye bolezni, 2012, no. 3, pp. 90-95 (in Russian).

13. Mena A., Meijide H., Rodríguez-Osorio I. Liver-related mortality and hospitalizations attributable to chronic hepatitis C virus co-infection in persons living with HIV. HIV Med, 2017, vol. 18, no. 9, pp. 685-689. DOI: 10.1111/hiv.12502

14. Kravchenko A.V., Aksenova V.A., Gurkina L.A. The HIV integrase inhibitor raltegravir as part of antiretroviral therapy schemes in patients with HIV infection and hepatitis. Infektsionnye bolezni, 2015, no. 3, pp. 5-11 (in Russian).

15. Kaur K., Gandhi M.A., Slish J. Drug-Drug Interactions among Hepatitis C Virus (HCV) and Human Immunodeficiency Virus (HIV) Medications. Infect. Dis. Ther., 2015, vol. 4, no. 2, pp. 159-172. DOI: 10.1007/s40121-015-0061-2

16. Manapova E.R., Fazylov V.Kh., Beshimov A.T. Efficacy of antiviral treatment of chronic hepatitis C in patients with HCV/HIV co-infection in the comparative aspect. Infektsionnye bolezni: novosti, mneniya, obuchenie, 2017, vol. 21, no. 4, pp. 51-56 (in Russian).

17. Yuschuk N.D., Maximov S.L., Ivanov L.M., Klimova Ye.A., Znoyko O.O., Kravchenko A.V. The combined therapy of chronic hepatitis with pegilated interferon $\alpha-2 \mathrm{a}$ and ribavirin in patients with HIVinfection and patients with HCV monoinfection. Rossiiskii zhurnal gastroenterologii, gepatologii, koloproktologii, 2009, vol. 19, no. 1, pp. 35-42 (in Russian).

18. Yushchuk N.D., Klimova E.A., Znoiko O.O., Karetkina G.N., Maksimov S.L., Martynov Yu.V., Shukhov V.S., Dudina K.R. [et al.]. Protokol diagnostiki i lecheniya bol'nykh virusnymi gepatitami B i C [The Procedure for diagnostics and treatment of patients with virus hepatitis B and C]. Rossiiskii zhurnal gastroenterologii, gepatologii, koloproktologii, 2010, vol. 20, no. 6, pp. 4-60 (in Russian).

19. Kanestri V.G., Kravchenko A.V., Gankina N.Yu. Hepatotoxicity of antiretroviral therapy in HIV-infected patients. Epidemiologiya i infektsionnye bolezni. Aktual'nye voprosy, 2014, no. 1, pp. 31-36 (in Russian).

20. Azovtseva O.V., Arkhipova E.I., Arkhipov G.S. Clinical and genotypic features of co-infection with hepatitis C virus and HIV. VICh-infektsiya i immunosupressii, 2010, vol. 2, no. 2, pp. $42-47$ (in Russian).

Maslyakov V.V., Aristanbekova M.S. Procedure for predicting progressing hepatic fibrosis in patients with human immunodeficiency and hepatitis c coinfection. Health Risk Analysis, 2020, no. 2, pp. 143-151. DOI: 10.21668/health.risk/2020.2.16.eng

Received: 18.07.2019

Accepted: 03.06.2020

Published: 30.06 .2020 